\title{
Oastea Domnului: the Army of the Lord in Romania*
}

\author{
TOM KEPPELER
}

It is over three years since the world's attention turned to the events in Romania that ultimately led to the fall of dictator Nicolae Ceausescu and his repressive regime. With the opening of its borders, this beautiful and sometimes perplexing Balkan country became the focus of multiple aid organisations, mission groups, churches, evangelists and faith healers as well as individual entrepreneurs. For most, Romania was a novelty: a European country with an educated populace but with Third World living standards; a country whose warm and hospitable people caught many first-time visitors by surprise; a country where that same effusive hospitality and graciousness often concealed the darker side of Romanian culture, a side characterised by bribes, favouritism and patronage.

For most western visitors, then, Romania was an unknown quantity. To be sure, many Christian visitors came having heard or read of the large Baptist and Pentecostal churches with their fervent church services and meetings. In contrast, the Orthodox Church to many represented a compromised state church which had sold its birthright to the communists for a pot of privileged porridge. It therefore came as a surprise to many visitors to discover in the context of the Orthodox Church a strong and vibrant renewal movement: Oastea Domnului, the Army of the Lord. This grassroots movement today is in a unique position on the religious landscape of Romania. Perhaps its greatest challenge and task is remaining true to its mission of spiritual revival, of 'preaching the crucified and risen Christ' in the context of the Romanian Orthodox Church.

\section{The Army of the Lord - History}

The history of this unique movement provides a challenging legacy as Oastea Domnului seeks to remain true to the mandate of its founder, Iosif Trifa. Trifa, ordained to the Orthodox priesthood in 1910, laboured during the first ten years of his ministry in Avram Iancu, a small village in Transylvania near the Apuseni Mountains. During this time he experienced great personal tragedy, losing his wife and several of his children to accident and illness. In 1921 Archbishop Balan of the Sibiu Synod called Trifa to Sibiu where he was named 'professor-priest' at the institute of theology. One of Balan's motives was to try to raise the spiritual morale of the population in the

*A document about the persecution of the Army of the Lord from the Christian Committee for the Defence of Religious Rights in Romania, dated 23 August 1978, was published in Religion in Communist Lands, Vol. 8, no. 4, 1980, pp. 314-17. A version of Tom Keppeler's article was published in the April 1993 issue of Evengelical Missions Quarterly, Box 794, Wheaton, IL 60189. 
context of the Orthodox Church. He and Trifa planned to publish a magazine, which Trifa proposed to call Lumina satelor (Light to the Villages). Trifa was editor-in-chief, working in conjunction with a group of theologians from the seminary. Trifa's desire and vision was to instil a new 'spirit' into the Orthodox Church, his idea being to put 'the knowledge of Christ above the dogmas of the church'.

The events of history often turn on very small hinges. Indeed, the beginning of Oastea Domnului was an insignificant event that took place on New Year's Eve 1922. It was around midnight, and Trifa was in his room preparing an article for the next edition of Lumina satelor, when a group of drunkards milling about on the street stopped under his window. In his own words:

On the eve of New Year 1923 I was reflecting on all my activities of the last ten years as a priest in the village as well as the past year as editor of Lumina satelor. I was thinking with sorrow about the vanity of the past eleven years of shouting in the desert without a trace of fruit. It was late at night. Under the window of my house, just then, passed a boisterous group of drunkards. This only increased my sorrow. I fell to my knees crying and I prayed to the Lord to help me in the year that lay ahead to labour with more success.

In this night, the Spirit of the Lord inspired me with the idea of a resolution. A resolution that we would publish in the following edition of the gazette Lumina satelor. In this edition, I would call my readers to enter this New Year with a decision, a resolution to fight against drunkenness, profanity and other sins. Through the signing of a declaration, we would call our readers to make a decision to fight against sin. We would call them to volunteer to fight a kind of fiery battle against sins. With this beginning came what developed into the movement 'Oastea Domnului'.'

What Wesley was to the Anglican Church, Trifa was to the Romanian Orthodox Church. As Wesley's preaching and ministry drew crowds from the working classes, so Trifa's as well was a ministry that grew among the villagers and workers of the fields. In the years to come, Oastea Domnului grew as a lay renewal movement within the Orthodox Church. People gathered in homes and in small groups for Bible study and prayer. Meetings were held in churches where members of Oastea Domnului preached to those gathered. Trifa died in 1938, but not before leaving behind many books and articles that were to become the charter for Oastea Domnului. Trifa's successor Ioan Marini and others also contributed to the writings of Oastea Domnului. By the time the communists took power in 1948, Oastea Domnului had its own publishing house based in Sibiu, and published its own newspaper, Isus biruitorul (Jesus the Victor); it was a strong grassroots movement, led by Traian Dorz (Marini had died in 1947). When the communists took power, the printing house was shut down, the movement was declared illegal and its leaders were imprisoned. However, Oastea Domnului continued its activities underground and the movement continued to grow.

As mentioned, Trifa's writings were extensive. Probably the clearest presentation of his vision of the purpose and strategy of Oastea Domnului is contained in his book Ce este Oastea Domnului? (What is Oastea Domnului?). Among the many subjects Trifa discusses in this work, four main themes stand out.

The first theme that is repeated throughout the work is the centrality of Christ and the cross. Trifa writes often of the importance of submission to these.

Oastea Domnului seeks to bring sinners to the source of righteousness and power ... to Jesus the Saviour. With this mark began the fight of Oastea Domnului and the Lord has blessed this work.... We must live a life of 
victory, but we can live this life only by receiving the Lord Jesus and the gifts of victory which are made possible to us through the sacrifice of the cross at Golgotha. Through the sacrifice of the cross at Golgotha, Satan was defeated definitively. The victory of the Lord was a definitive victory. But the victory of the cross for us has no value if we do not receive Jesus who brings us the gift of victory. ${ }^{2}$

Second, one finds much material devoted to moral renewal, both at the individual and national level. Indeed, Oastea Domnului began in part as a temperance movement to fight against the abuses of alcohol and to raise the decayed moral standard of the nation. Trifa writes:

I have written much about these two sins, drunkenness and profanity, which Satan has used to murder many a soul. But I must add that Oastea Domnului does not fight only against these two sins. There are others who are just as drunk, not with alcohol, but with anger, pride, envy, debauchery, greed. Oastea Domnului is a movement of cleansing, of renewal and of total change of those who enter this army. With Oastea Domnului, we preach a renewal of the soul, we preach a change of life's foundation, we preach a new life. ${ }^{3}$

Today, Oastea Domnului continues to emphasise abstinence from alcohol and tobacco as well as the importance of personal piety and holiness.

A third emphasis one finds in Ce este Oastea Domnului? is Trifa's commitment to the laity.

We who are with Oastea Domnului work more as so-called lay apostles. This is not a new thing. The lay apostle is the command of Scripture . . . beginning with the two women, the Samaritan woman and Mary Magdalene, who proclaimed Jesus upon hearing of him. Throughout Scripture we see examples of the lay apostle. It is sufficient to remember the word of St James in James 5:20. Every soul that comes to the Lord in truth is made a proclaimer of Him. That's the way it was at the beginning of Christianity, that's the way it should be now. There are those, though, who see in this a 'new danger'. They see it this way because they are the same ones who extinguished New Testament Christianity, living Christianity, witnessing and proclaiming Christianity. ${ }^{4}$

The role of the laity even today is one of the characteristics of Oastea Domnului. The preaching, the evangelism, the leading of local fellowships is all done by laymen. Professional or paid ministers are not part of Oastea Domnului's heritage nor of its present practice.

Fourth, Trifa expresses a love for and unwavering commitment to the Scriptures. The Scriptures are not only to be studied, but they are to be considered the weapon of the Oastea Domnului Christian.

The Holy Scriptures is not just a book like any other book. It is a book of God. A book through which God speaks about his plans. The Bible is a book through which God reveals his plan of salvation for us ... a Christian without the Bible is like a craftsman without his tools. The Bible to the Christian is like the plough to the farmer, the scissors to the tailor, the hammer to the blacksmith, the pen to the writer ... that is what the Bible must be for us. A soldier of the Lord without the Bible is like a soldier without his gun. ${ }^{5}$ 
Fellowships of Oastea Domnului must be, above all else, schools of the Bible. The Bible is a wonderful school. This school lasts a lifetime. A soldier of the Lord must be a hardworking scholar of the Bible. A hardworking reader of the Bible. ${ }^{6}$

In many respects Ce este Oastea Domnului?, published in 1934, is the blueprint for Oastea Domnului. The teachings and life of Trifa as well as those of Ioan Marini and the poet Traian Dorz are the heritage the movement has today as it tries to define and clarify its mission in the Romanian religious context and in society at large.

\section{Tensions Today}

Many within the Oastea Domnului movement thought that with the new freedoms brought about by the fall of the Ceauşescu regime, evangelism and fervour for ministry and reaching the lost would be at the forefront of the agenda. Although the new freedoms have brought many new opportunities, the movement as a whole has in many respects turned inward, and there has been considerable debate, discussion and infighting over several issues. I have discussed this problem of disunity with a number of men on the national leadership council, and there seem to be varying opinions as to its causes.

One issue that rises quickly to the surface is the relationship of Oastea Domnului with the Orthodox Church. During the years the communists were in power, Oastea Domnului was not officially recognised by the Orthodox church hierarchy and even experienced staunch opposition from the church. Trifa, the founder of the movement, had been defrocked and banned by the church. Since the fall of the communist regime in December 1989, the Orthodox Church has rehabilitated Trifa posthumously and has also given official recognition to Oastea Domnului. Many within the movement question the motives of such a move. Many fear that it arises out of a desire by the church hierarchy to exercise control over the movement and eventually to absorb and diffuse it.

The issue of the relationship with the Orthodox Church is a very sensitive one. There seem to be two prevailing opinions within the movement. One side contends that the place of Oastea Domnului is in the church. Meetings should be held in local churches and the priests and local bishops need to be informed about, as well as involved in, these activities. This side also contends that Oastea Domnului is under the authority of the church and points out over and over again that Oastea Domnului is not a neoprotestant evangelical group but an Orthodox one.

The other side sees the mandate of Oastea Domnului as being a missionary force to the Orthodox Church without being under its control. Those who hold this position see it as their calling to be salt and light and to preach the gospel in the context of a spiritually dead, institutional church. This seems to be in keeping with the vision of Trifa as set out in Ce este Oastea Domnului? In keeping this purpose in mind it is important to make a distinction between the relationship of Oastea Domnului with the Orthodox church hierarchy and its relationship with local churches. One member of the Oastea Domnului national council from Moldova commented on this distinction. In reference to the relationship with the church hierarchy he stated that

I believe we will finish our journey on this earth without having a good understanding. Because . . . if they did not understand Jesus Christ, how can they understand where we're coming from? Only priests who have a pure soul before the Lord will be able to understand us.... There could be an 
understanding to a small extent, until the moment that they see the effect. Because as soon as God develops the work, as soon as people within the Orthodox Church commit their lives to Christ, making a covenant with God, I don't know that there won't exist reservations on the part of the Orthodox church structure. ${ }^{7}$

In reference to local situations, it was pointed out that the relationship of Oastea Domnului to the local church really depends on the local priest. This same leader continued:

There are communities where the local priest collaborates with Oastea Domnului. They open the doors of the churches. And the people, hearing and seeing our activities in the context of the church, will have more trust and confidence in us. If the local priest is not predisposed to us in this way, he will never open the church to Oastea Domnului. ${ }^{8}$

Another leader on the national council and a man who was very close to Traian Dorz said of the role of Oastea Domnului that 'the first and foremost problem for us today is the same as Iosif Trifa had at the beginning: to "rebirth" Jesus Christ in the Orthodox Church'. ${ }^{9}$ Although at present he saw a fairly good relationship with the Orthodox church hierarchy, he pointed out that

there is a degree of reticence in certain areas, as there has always been on the part of the church. Along with the fact that there are those that tolerate us, at the same time there are those who don't see us with a good eye, but rather look at us as schismatics in the church. ${ }^{10}$

The second issue which has been the cause of much debate is the relationship of Oastea Domnului with foreigners. Historically, there has always been within the movement a degree of fear of foreign influence. There are several reasons for this fear. First, it has often been motivated by a desire to keep false teaching out of the movement, or indeed anything that might contaminate the pure preaching of the gospel. Second, it has been a result of many years of repression and underground ministry forced upon the movement by the communists: security and trust were essential. This attitude still carries over into the more open and free Romania of today. Third, it is fuelled by simple lack of contact between the movement and the West over the past 40 years. Unlike the Baptist, Brethren or Pentecostal denominations, Oastea Domnului has no 'sister' denominations or similar organisations anywhere outside Romania.

There is a good deal of discussion regarding ties with fellow Christians going on today, contributing to the confusion and discord in the movement as a whole. The activities of numerous western groups which have established contact with certain fellowships in Oastea Domnului have fuelled the fire of those opposed to involvement with foreigners. I have spoken about this issue with a number of members of the national leadership board, where there seems to be a desire for cooperation and involvement with foreign groups, provided these understand the unique role and purpose of Oastea Domnului in Romania. One member spoke very strongly about the apparent hypocrisy on the part of some in Oastea Dommului when it comes to relationships with foreigners.

The foreigners I've known have never done us any harm. I've had relationships with foreigners since I can remember, since I was a child. But the Oastea Domnului didn't accept contact with foreigners in the past because of the danger this represented (fines, imprisonment). Only those with 
courage had relationships with foreigners - that is to say, not foreigners but brothers from different countries. They risked their lives and their health, to help us here in Romania. We cried with them, and rejoiced with them.... I have opposition from some today because I have relationships with foreigners. It is a problem of understanding. They want to rejoice in books from outside but not to have relationships with the outside. ${ }^{11}$

\section{Future Challenges}

Oastea Domnului is a unique movement: while it is not unlike other renewal movements which have arisen throughout church history, it is the only one which is indigenous to Romania. Romania is historically an Orthodox country; Trifa, the founder, was an Orthodox priest. The Christian writers which Oastea Domnului looks to are Romanian - Iosif Trifa, Ioan Marini, Traian Dorz and others. The hymnology and poetry of Oastea Domnului are Romanian in origin. Oastea Domnului represents a kind of reformation movement in the Orthodox Church. Where local Oastea Domnului fellowships are preaching and living the gospel, there is spiritual life and vitality.

There have always inevitably been tensions between the movement and the Orthodox Church, and these are most likely to continue. It is quite possible that the movement will become more polarised in the future, with the more progressive, evangelical wing continuing to grow, and possibly breaking off eventually.

The relationship of Oastea Domnului with foreigners may also continue to be a source of tension. The relationships some fellowships have forged with churches outside Romania are often looked on enviously by others within the movement, because of the material aid involved. However, as Romania is now a relatively free and open country, continued contact with Christians outside Romania and ensuing relationships will be inevitable. The isolation that the communist era provided no longer exists and Oastea Domnului will have to rise to the consequent new challenges.

There are and will continue to be theological tensions within the movement. Many fellowships are active in building their own places to meet and worship without interference from unsympathetic local priests. Many such fellowships are in a real sense operating like independent churches. Practical issues such as local leadership, forms of worship and even sacraments such as baptism and communion could become subjects of controversy, especially as many Oastea Domnului fellowships are trying to maintain their Orthodox roots while at the same time functioning independently. A final question which arises as more autonomous fellowships come into existence is how Oastea Domnului will be able to remain true to its founder's vision of evangelism and mission in the Romanian Orthodox Church. Trifa's last exhortation in Ce este Oastea Domnului? remains a challenge for Oastea Domnului today: 'My dear brethren, fight the good fight, fulfil your duty and journey so that in the end we might all meet again in the heavenly Jerusalem, in the place the Lord has prepared for us to live with Him in eternity.' ${ }^{12}$

\section{Notes and References}

I Iosif Trifa, Ce este Oastea Domnului? (Editura si tiparul Tipografiei Oastea Domnului, Sibiu, 1934), p. 231.

2 ibid., p. 7.

3 ibid., p. 122. 
4 ibid., p. 129.

5 ibid., pp. 93, 94.

6 ibid., p. 177.

7 Interview with a member of 'sfat fratesc' from Moldova, 23 July 1991.

8 ibid.

${ }^{9}$ Interview with member of 'sfat fraţesc' from Transylvania, 9 August 1991.

10 ibid.

11 Moldova interview.

12 Trifa, op. cit., p. 240. 